\title{
Chlorogenic acid induces apoptosis, inhibits metastasis and improves antitumor immunity in breast cancer via the NF-кB signaling pathway
}

\author{
ANQI ZENG ${ }^{1,3}$, XIN LIANG $^{2}$, SHAOMI ZHU ${ }^{2}$, CHI LIU $^{2}$, SHU WANG $^{1}$, QINXIU ZHANG $^{2}$, \\ JUNNING ZHAO $^{1,3}$ and LINJIANG SONG ${ }^{2}$ \\ ${ }^{1}$ West China School of Pharmacy, Sichuan University, Chengdu, Sichuan 610041; \\ ${ }^{2}$ School of Medical and Life Sciences/Reproductive and Women-Children Hospital, \\ Chengdu University of Traditional Chinese Medicine, Chengdu, Sichuan 610072; \\ ${ }^{3}$ Sichuan Academy of Chinese Medical Science, Chengdu, Sichuan 610041, P.R. China
}

Received April 29, 2020; Accepted November 13, 2020

DOI: $10.3892 /$ or.2020.7891

\begin{abstract}
Breast cancer which is the most common type of diagnosed cancer among women worldwide possesses metastatic potential, multi-drug resistance, and high mortality. The NF- $\kappa \mathrm{B}$ signaling pathway has been revealed to be abnormally activated in breast cancer cells and closely associated with high metastasis and poor prognosis. In the present study, it was reported that chlorogenic acid (CGA), a potent NF- $\kappa$ B inhibitor derived from coffee, exerted antitumor activity in breast cancer. MTT and colony formation assays were conducted and it was revealed that CGA inhibited viability and proliferation in breast cancer cells. Additionally, CGA significantly induced apoptosis and suppressed migration and invasion in breast cancer cells. Notably, immunofluorescence analysis confirmed that CGA could efficiently suppress nuclear transcription of NF- $\kappa \mathrm{B}$ p65. In addition, results of western blotting demonstrated that CGA markedly impaired the NF- $\mathrm{B}$ and EMT signaling pathways. The antitumor effect of CGA was evaluated in a subcutaneous tumor mouse model of 4T1 cells, and the results revealed that CGA markedly retarded tumor growth and prolonged the survival rate of tumor-bearing mice. Notably, CGA inhibited pulmonary metastasis of 4T1 cells by enhancing the proportion of $\mathrm{CD}^{+}$and $\mathrm{CD} 8^{+}$ $\mathrm{T}$ cells in spleens of mice, which indicated an improvement
\end{abstract}

Correspondence to: Dr Linjiang Song, School of Medical and Life Sciences/Reproductive and Women-Children Hospital, Chengdu University of Traditional Chinese Medicine, 17 Renmin South Road, Section 4, Chengdu, Sichuan 610072, P.R. China

E-mail: linjsong_scu@163.com

Dr Junning Zhao, West China School of Pharmacy, Sichuan University, 17 Renmin South Road, Section 3, Chengdu, Sichuan 610041, P.R. China

E-mail: zarmy@189.cn

Key words: chlorogenic acid, NF- $\mathrm{BB}$, metastasis, antitumor immunity, breast cancer of antitumor immunity. In conclusion, the present present study demonstrated that CGA improved antitumor immunity, exerting antitumor and anti-metastatic effects by impairing the NF- $\mathrm{\kappa}$ /EMT signaling pathway, suggesting that CGA may serve as a potential candidate for therapy of breast cancer.

\section{Introduction}

Based on literary data, breast cancer comprises $30 \%$ of all diagnosed carcinomas and is the second leading cause of cancer-related mortality among women (1). A total of 208,8849 new cases of breast cancer and 626,679 mortalities due to breast cancer occurred worldwide in 2018 (2), and it has been reported that there will be 279,100 new breast cancer cases, as well as 42,690 mortalities due to breast cancer in 2020 in the United States (3). Despite great progress in improving the survival rates of patients with breast cancer in recent years, breast cancer, particularly 'triple-negative' breast cancer (TNBC), remains a threat to the health of women. TNBC, which is characterized by absent or low expression of estrogen receptor (ER), progesterone receptor (PR) or human epidermal growth factor receptor 2 (HER2), exhibits intensive invasion, high metastasis and poor prognosis (4). Compared with patients without TNBC, patients with advanced TNBC experience an aggressive clinical outcome with a poor prognosis and high metastasis to distant organs including the lung, liver, brain and lymphatic nodes (5). Distant metastasis, which has become the leading obstacle to breast cancer therapy, accounts for the majority of breast cancer-related deaths (6). However, there are currently few effective methods to treat the metastasis and recurrence of breast cancer, and thus it is urgent to develop novel therapeutic agents for breast cancer.

It is well known that various signaling pathways are involved in breast cancer progression and metastasis, including $\mathrm{NF}-\kappa \mathrm{B}(6,7)$. NF- $\kappa \mathrm{B}$, which was defined as a DNA-binding protein in 1986, is widely involved in various human disorders including inflammatory diseases, viral infection and metabolic disorders, as well as cell proliferation and oxidative stress (9-12). With regard to breast cancer, dysregulated 
activation of NF- $\mathrm{BB}$ is involved in the regulation of cell proliferation, differentiation, apoptosis, angiogenesis and metastasis (13-16). Epithelial-mesenchymal transition (EMT), which is critical to primary metastasis of breast cancer, is regulated by the NF- $\mathrm{KB}$ signaling pathway (17). Moreover, previous studies have revealed that blockade of abnormally activated NF- $\mathrm{KB}$ using inhibitors could induce apoptosis and suppress metastasis in breast cancer cells (18-20). Thus, inhibition of NF- $\mathrm{KB}$ offers a potential strategy to the therapy of breast cancer. While increased effort has been made in the discovery of potent NF- $\mathrm{KB}$ inhibitors and numerous inhibitors targeting NF- $\kappa B$ have been reported, to date, few NF- $\kappa B$ inhibitor drugs have been approved by the Food and Drug Administration. Therefore, it is urgent to develop novel NF-kB inhibitors for the treatment of breast cancer.

Chlorogenic acid (CGA), a polyphenol compound that is abundant in the human diet, such as coffee, possesses multiple biological activities, including anticarcinogenic, antibacterial, anticancer and antioxidant effects (21-24). CGA has been reported to be non-toxic and safe in animals and humans (25). Accumulating evidence has revealed that CGA suppresses migration and invasion, and induces apoptosis in numerous cancer cell lines including colon, breast and lung $(25,26)$. For instance, Feng et al (27) demonstrated that CGA inhibited lung cancer cell proliferation by suppressing the NF- $\mathrm{KB}$ and MAPK signaling pathways. Furthermore, Kang et al (28) revealed that CGA derived from coffee impaired colorectal cancer cell metastasis by suppressing NF- $\kappa \mathrm{B}$, MEK and T-LAK cell-originated protein kinase. Additional studies indicated that CGA could attenuate LPS-induced acute kidney injury, protect cardiomyocytes and ameliorate lead-induced renal damage via suppressing the NF- $\mathrm{KB}$ signaling pathway (29-31). Considering the important role of NF- $\mathrm{kB}$ in breast cancer, it was hypothesized that CGA, a potent NF- $\kappa \mathrm{B}$ signaling inhibitor, may be a potential drug for clinical therapy of breast cancer.

The present study aimed to investigate the role of CGA in proliferation, apoptosis, migration and invasion in breast cancer cell lines. Moreover, two mouse models of breast cancer were established to further evaluate the therapeutic activity of CGA. It was hypothesized that CGA could slow tumor growth and suppress pulmonary metastasis by impairing the NF- $\mathrm{kB}$ signaling pathway.

\section{Materials and methods}

Materials and reagents. CGA (Fig. 1A) (purity, $>98 \%$, as measured by high-performance liquid chromatograph analysis; purchased from J\&K Scientific, Ltd.) was made into a stock solution $(40 \mathrm{mM})$ by dissolving in DMSO, and was stored at $-20^{\circ} \mathrm{C}$ for further use. The medium containing $0.1 \%$ DMSO served as the control.

MTT and Hoechst 33258 were purchased from Sigma-Aldrich (Merck KGaA), while the Annexin V-FITC apoptosis detection kit was obtained from 4A Biotech Co., Ltd. The mouse monoclonal antibody of Ki-67 (dilution: 1:500, cat. no. SAB5300423) was purchased from EMD Millipore. Primary antibodies against cleaved caspase-3 (product no. 9661; dilution 1:1,000), NF-kB p65 (product no. 8242; dilution 1:1,000), phosphorylated (p)-IкB $\alpha$ (product no. 2859; dilution 1:1,000), N-cadherin (product no. 13116; dilution 1:1,000), E-cadherin (product no. 14472; dilution 1:1,000) and $\beta$-actin (product no. 3700; dilution 1:1,000) used for western blotting were obtained from Cell Signaling Technology, Inc.

Cell lines and cell culture. The human breast cancer cell lines MDA-MB-231 and MDA-MB-453, human mammary epithelial cells MCF-10A and the murine breast cancer cell line 4T1 were purchased from the American Type Culture Collection. All cells were cultured in DMEM or RPMI-1640 media (Gibco; Thermo Fisher Scientific, Inc.) containing 10\% heat-inactivated FBS (Hyclone; Cytiva) and 1\% antibiotics (penicillin and streptomycin) in $5 \% \mathrm{CO}_{2}$ at $37^{\circ} \mathrm{C}$.

Cell viability. Cells were seeded into 96-well plates at a density of $2-6 \times 10^{3}$ cells/well and cultured for $24 \mathrm{~h}$. Then, cells were treated with various concentrations $(0,0.625,1.25,2.5,5,10$, 20,40 and $80 \mu \mathrm{M}$ ) of CGA for 24,48 and $72 \mathrm{~h}$. Subsequently, $20 \mu \mathrm{l}$ MTT solution $(5 \mathrm{mg} / \mathrm{ml})$ was added to each well and incubated for another $2-4 \mathrm{~h}$ at $37^{\circ} \mathrm{C}$. The culture medium was replaced with $150 \mu \mathrm{l}$ DMSO, which is used to dissolve formazan secreted by living cells. A Spectra MAX M5 microplate spectrophotometer (Molecular Devices, LLC) was used to measure absorbance $(570 \mathrm{~nm})$ of each well. The data are obtained from $\geq 3$ independent experiments.

Colony formation assay. Briefly, cells were seeded at a determined number (300-500 cells/well) in 6-well plates and exposed to various concentrations $(0,5,10$ and $20 \mu \mathrm{M})$ of CGA for $\sim 12$ days. The medium was replaced with fresh culture medium with or without CGA every 3 days. Cells were washed gently with cold PBS, fixed with methanol for $20 \mathrm{~min}$ and stained with crystal violet solution $(0.5 \%, \mathrm{~m} / \mathrm{v})$ for $25 \mathrm{~min}$ at room temperature. Finally, the colonies (number of cells, >50) were imaged and counted using a florescence microscope (magnification, x10; Olympus Corporation).

Morphological analysis via Hoechst staining. Cells $\left(1 \times 10^{5}\right.$ cells/well) were seeded into 6-well plates and incubated with various concentrations $(0,5,10$ and $20 \mu \mathrm{M})$ of CGA for $24 \mathrm{~h}$, followed by staining with Hoechst 33258 dye solution for $10 \mathrm{~min}$ at $25^{\circ} \mathrm{C}$ based on the manufacturer's instructions. Then, the nuclear morphologies of treated cells were observed and imaged with a fluorescence microscope (magnification, x100; Olympus Corporation).

Cell apoptosis. Cells ( $1 \times 10^{5}$ cells/well) were seeded into 6-well plates and incubated with various concentrations $(0,5,10$ and $20 \mu \mathrm{M}$ ) of CGA for $24 \mathrm{~h}$. Then, cells were harvested, washed with cold PBS three times and incubated with Annexin V/PI dual labeling kit (4A Biotech Co., Ltd.) according to the manufacturer's instructions. Finally, apoptotic cells were detected via flow cytometry (BD Biosciences). The data was analyzed by FlowJo 7.6 software (Tree Star, Inc.).

Wound-healing assay. Cells ( $1 \times 10^{5}$ cells/well) were seeded into 6-well plates and were scraped with a sterile $100-\mu 1$ pipette tip when cell confluence reached $80-90 \%$. Then, the cultured medium was replaced with fresh medium $(0.5 \%$ FBS) 
containing determined concentrations $(0,5,10$ and $20 \mu \mathrm{M})$ of CGA. After treatment with CGA for $24 \mathrm{~h}$, the cells were washed with cold PBS and imaged using a microscope (Olympus Corporation).

Body chamber invasion assay. Briefly, $1 \times 10^{5} 4 \mathrm{~T} 1$ or $5 \times 10^{6}$ MDA-MB-231 cells, which were suspended in $100 \mu 1 \mathrm{FBS}-$ free culture medium, were added in the upper chamber that was precoated with Martrigel. The lower chamber was filled with $600 \mu \mathrm{l}$ cultured medium that contained 10\% FBS. Various concentrations $(0,5,10$ and $20 \mu \mathrm{M})$ of CGA were added in the upper chamber medium. After $48 \mathrm{~h}$, invasive cells located on the downside of the filter were washed with cold PBS, fixed in methanol for $15 \mathrm{~min}$ and incubated with crystal violet $(0.5 \%, \mathrm{~m} / \mathrm{v})$ for $20 \mathrm{~min}$ at room temperature. Finally, invasive cells located on the membrane were imaged and counted with a microscope (Olympus Corporation).

Western blot analysis. Cells with various treatments $(0,5$, 10 and $20 \mu \mathrm{M}$ of CGA) were harvested, washed with cold PBS for three times and lysed with RIPA buffer (Beyotime Institute of Biotechnology). Concentration of protein was determined by BCA method and the OD value of protein was measured by Spectra MAX M5 microplate spectrophotometer (Molecular Devices, LLC). Then, equal amounts of proteins $(30-50 \mu \mathrm{g})$ of each sample were separated via SDS-PAGE (10\%, w/v), and the separated proteins on the gel were transferred onto PVDF membranes. Subsequently, membranes containing targeted proteins were blocked with non-fat milk for $1 \mathrm{~h}$ at $37^{\circ} \mathrm{C}$ and treated with specific primary antibodies overnight at $4^{\circ} \mathrm{C}$. After incubation with the corresponding horseradish peroxidase-conjugated secondary antibodies (cat. no. BA1056; dilution 1:20,000; Wuhan Boster Biological Technology, Ltd.) for $1 \mathrm{~h}$ at $37^{\circ} \mathrm{C}$, protein bands were visualized with an enhanced chemiluminescence kit (EMD Millipore).

Immunofluorescence analysis. Cells were cultured on circular glasses in 24-well plates and underwent different treatment regimes. Cells were fixed with $4 \%$ paraformaldehyde at $25^{\circ} \mathrm{C}$ for $10 \mathrm{~min}$, treated with permeabilization solution (1\% Triton X-100) for $15 \mathrm{~min}$, washed with PBS three times and blocked with BSA (5\%, m/v; Biological Technology Co., Ltd.) at room temperature for $1 \mathrm{~h}$. After being treated with corresponding primary antibodies $(\mathrm{NF}-\kappa \mathrm{B}$ p 65 ; product no. 8242; dilution 1:500; Cell Signaling Technology, Inc.) overnight at $4^{\circ} \mathrm{C}$, cells were washed gently with cold PBS three times and incubated with FITC-conjugated goat anti-rabbit IgG secondary antibody (product no. A0562; 1:500; Beyotime Institute of Biotechnology) at room temperature for $1 \mathrm{~h}$. Cells were stained with DAPI (dilution $1: 10,000$ ) at $25^{\circ} \mathrm{C}$ for $10 \mathrm{~min}$ and imaged via Laser Scanning Confocal Microscopy (Leica Microsystems $\mathrm{GmbH}$ ).

In vivo antitumor assessment. Animal experiments in the present study were approved by the Ethics Committee of Chengdu University of Traditional Chinese. Mice were kept in a specific-pathogen-free (SPF) condition facility with an air-conditioned room at $25 \pm 2^{\circ} \mathrm{C}$ with a relative humidity of $40-70 \%$, and a 12-h light/dark cycle. Twenty-seven female BALB/c mice (age, 6-8 weeks; weight, 18-20 g) were purchased from Beijing HFK Bioscience Co., Ltd. 4T1 cells $\left(1 \times 10^{6}\right.$ cells per mouse) suspended in culture medium with no FBS and antibodies were subcutaneously injected into the right flank of every $\mathrm{BALB} / \mathrm{c}$ mice. When the tumor volume reached $\sim 100 \mathrm{~mm}^{3}$, tumor-bearing mice were randomly divided into three groups (control group, 20 and $40 \mathrm{mg} / \mathrm{kg} ; \mathrm{n}=9$ ), and intraperitoneally administered different doses of CGA every 2 days. The tumor volume was calculated according to the following formula: $\mathrm{V}=0.5 \times \mathrm{LW}^{2}$, where $\mathrm{L}$ represents the length of the tumors and $\mathrm{L}$ represents the width of the tumors. At the termination of the experiment (18 days after CGA treatment), three mice from each group were euthanized via cervical dislocation, while the remaining tumor-bearing mice were maintained for an additional time period to record the survival rate. Tumors isolated from mice in the various treated groups were imaged, weighed and fixed with paraformaldehyde $(4 \%, \mathrm{w} / \mathrm{v})$ for $24 \mathrm{~h}$ at $25^{\circ} \mathrm{C}$ for further immunohistochemistry evaluation. For immunohistochemistry, the frozen $\left(-20^{\circ} \mathrm{C}\right) 4-\mu \mathrm{m}$-thick sections were incubated with primary rabbit anti-mouse antibodies Ki-67 (product no. 9449; dilution 1:500), cleaved caspase-3 (product no. 9661; dilution 1:500), PD-L1 (product no. 13684; dilution 1:200), $\mathrm{N}$-cadherin (product no. 13116; dilution 1:500) and $\mathrm{p}-\mathrm{I} \kappa \mathrm{B} \alpha$ (product no. 2859; dilution 1:200) at $25^{\circ} \mathrm{C}$ for $1 \mathrm{~h}$, blocked with goat serum (10\% in PBS; Beyotime Institute of Biotechnology) at $25^{\circ} \mathrm{C}$ for $15 \mathrm{~min}$, and subsequently treated with biotinylated goat anti-rabbit immunoglobulin secondary antibody (dilution 1:1,000; cat. no. ab6721; Abcam) at $37^{\circ} \mathrm{C}$ for $30 \mathrm{~min}$. Finally, sections were incubated with streptavidin-peroxidase and DAB solution (Beijing Solarbio Science \& Technology Co., Ltd.) at $37^{\circ} \mathrm{C}$ for $20 \mathrm{~min}$ to visualize the biotinylated goat anti-rabbit immunoglobulin. Organs (heart, liver, spleen, lung and kidney) were isolated from mice in different groups and were fixed with paraformaldehyde $\left(4 \%\right.$, w/v) for $24 \mathrm{~h}$ at $25^{\circ} \mathrm{C}$ for further histopathological analysis. Sections (4- $\mu \mathrm{m}$-thick) were stained with hematoxylin $(1 \%)$ and eosin $(1 \%)$ at $25^{\circ} \mathrm{C}$ for $2-5 \mathrm{~min}$. Finally, the sections were visualized by light microscope.

Anti-pulmonary metastasis evaluation. For anti-pulmonary metastasis evaluation, 4T1 cells $\left(5 \times 10^{5}\right.$ cells per mouse) suspended in culture medium with no FBS and antibodies were intravenously injected into mice. Then, 2 days after inoculation, mice were randomly divided into three groups (control group, 20 and $40 \mathrm{mg} / \mathrm{kg} ; \mathrm{n}=3$ ), and intraperitoneally administered different doses of CGA every 2 days. After treatment with various doses of CGA for 14 days, the mice from each group were euthanized via cervical dislocation. Lung tissues were isolated, weighted and imaged. Metastatic nodules $\left(>3\right.$ and $<3 \mathrm{~mm}^{3}$ ) on lung tissues from each group were counted. Finally, lung tissues were fixed with paraformaldehyde $(4 \%, \mathrm{w} / \mathrm{v})$ for $24 \mathrm{~h}$ at $25^{\circ} \mathrm{C}$ for histopathological analysis. Sections (4- $\mu$ m-thick) were stained with hematoxylin (1\%) and eosin $(1 \%)$ at $25^{\circ} \mathrm{C}$ for $2-5 \mathrm{~min}$. Finally, sections were visualized by light microscope.

To investigate the effect of CGA on antitumor immunity, single-cell suspensions of spleens from various treated groups were prepared and stained with various antibodies CD3 (cat. no. 100236), CD4 (cat. no. 100406) and CD8 (cat. no. 100707; 
A
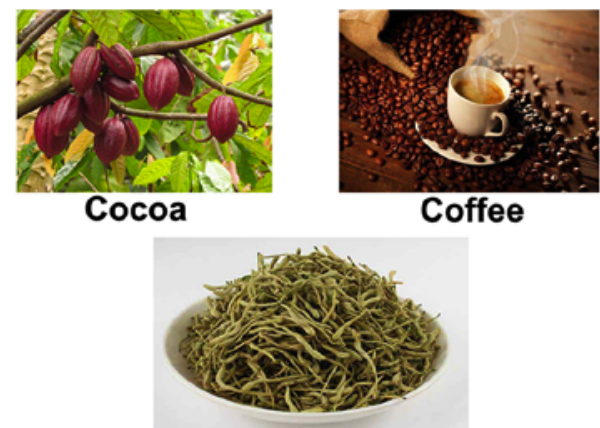

Coffee

Honeysuckle

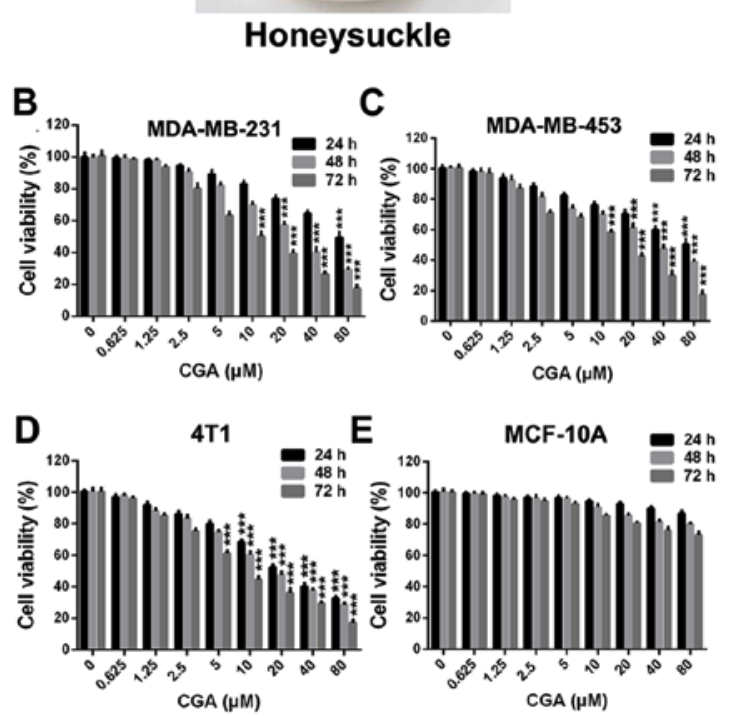

F $\quad \operatorname{CGA}(\mu \mathrm{M})$

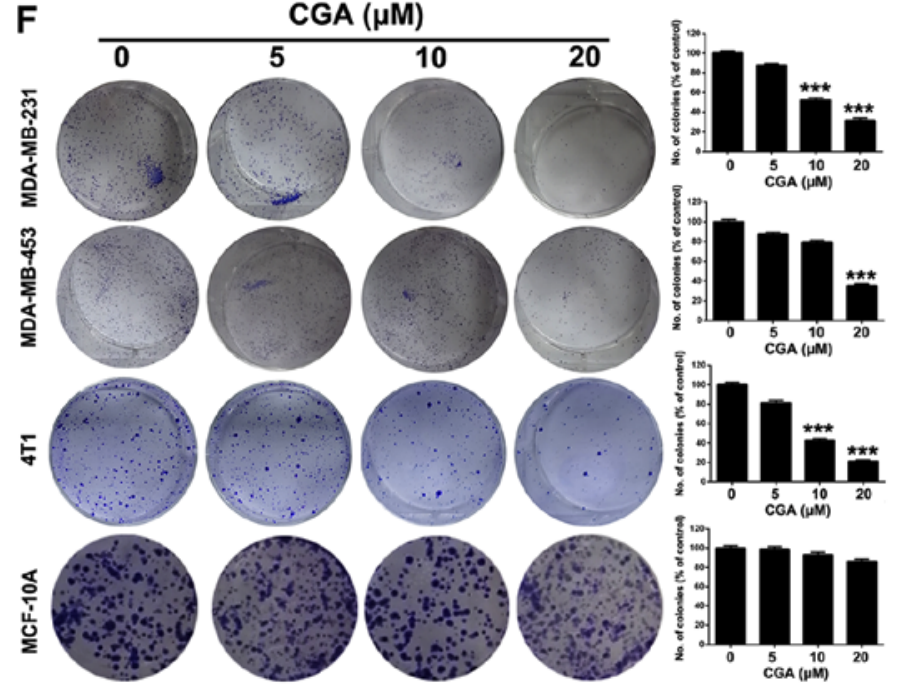

Figure 1. CGA suppresses the viability of breast cancer cell lines. (A) Natural sources and chemical structure of CGA. (B-D) Viabilities of breast cancer cells line of MDA-MB-231, MDA-MB-453 and 4T1 were measured by MTT assay after treatment with various concentrations of CGA $(0,0.625,1.25,2.5,5,10$, $20,40$ and $80 \mu \mathrm{M})$ for various time-points (24, 48 and $72 \mathrm{~h}$ ). (E) Viability of human mammary epithelial cells MCF-10A was measured by MTT assay after treatment with various concentrations of CGA for various time-points. (F) Abilities of colony formation of MDA-MB-231, MDA-MB-453, 4T1 and MCF-10A cells were measured after treatment with various concentrations of CGA $(0,5,10$ and $20 \mu \mathrm{M})$. Bars represent the means \pm SD of at least three independent experiments. ${ }^{* * * *} \mathrm{P}<0.001$ in comparison with the control group. CGA, chlorogenic acid.

all from BioLegend, Inc.) at $25^{\circ} \mathrm{C}$ for 30 min to analyze $\mathrm{CD} 4^{+}$ $\mathrm{T}$ cells and $\mathrm{CD}^{+} \mathrm{T}$ cells via flow cytometric analysis (FCM).

Statistical analysis. Data are presented as the mean \pm SEM of three independent experiments. GraphPad Prism 5 (GraphPad Software, Inc.) was used to analyze data in the present study. One-way ANOVA followed by Dunnett's post hoc test or Tukey's post hoc test were used for multi-group comparisons. $\mathrm{P}<0.05$ was considered to indicate a statistically significant difference.

\section{Results}

CGA inhibits the proliferation of breast cancer cell. In order to evaluate the cytotoxicity of CGA in breast cancer, MDA-MB-231, MDA-MB-453 and 4T1 cells were treated with various concentrations of CGA and cell viability was measured using an MTT assay. The viabilities of MDA-MB-231, MDA-MB-453 and 4T1 cells were significantly impaired by treatment with CGA (Fig. 1B-D). Additionally, CGA exhibited a notably dose- and time-dependent toxic effect on breast cancer cells (Fig. 1E). However, CGA had almost no influence on viability of human mammary epithelial cells (MCF-10A), suggesting that CGA could selectively cause toxicity in breast cancer cells.
A colony formation assay was conducted to further investigate the anti-proliferation effect of CGA on breast cancer. The colony formation ability of MDA-MB-231, MDA-MB-453 and 4T1 cells was significantly inhibited after treatment with various concentrations of CGA (Fig. 2F). Furthermore, the colony formation ability of MCF-10A cells was unaffected by treatment of CGA, which was consistent with the results of the MTT assay.

CGA induces breast cancer cells apoptosis. To examine whether the cytotoxicity of CGA in breast cancer resulted from cell apoptosis, Hoechst 33258 staining was conducted to detect the apoptotic induction ability of CGA. Treatment with CGA significantly changed the morphologies of MDA-MB-231 and 4T1 cells (Fig. 2A). Additionally, bright blue fluorescent condensed nuclei and nuclear fragmentations were observed in MDA-MB-231 and 4T1 cells after various treatments with CGA.

To further confirm the apoptotic induction ability of CGA, an Annexin V/PI dual staining assay was performed to detect the apoptotic rate in breast cancer cells. Compared with the control group $(1.27 \pm 0.98 \%)$, the apoptotic rate in MDA-MB-231 cells increased from $4.74 \pm 0.95$ to $15.10 \pm 1.26 \%$ $(\mathrm{P}<0.001)$ when the concentration of CGA was increased from 5 to $20 \mu \mathrm{M}$ (Fig. 2B). Similarly, treatment with $20 \mu \mathrm{M}$ CGA induced significant apoptosis $(22.65 \pm 1.79 \%$; $\mathrm{P}<0.001)$ in $4 \mathrm{~T} 1$ cells in comparison with the control group $(11.00 \pm 1.25 \%)$. 
A

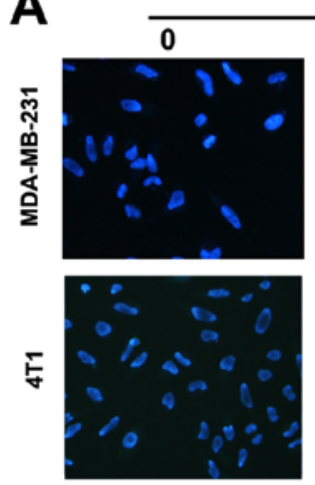

B
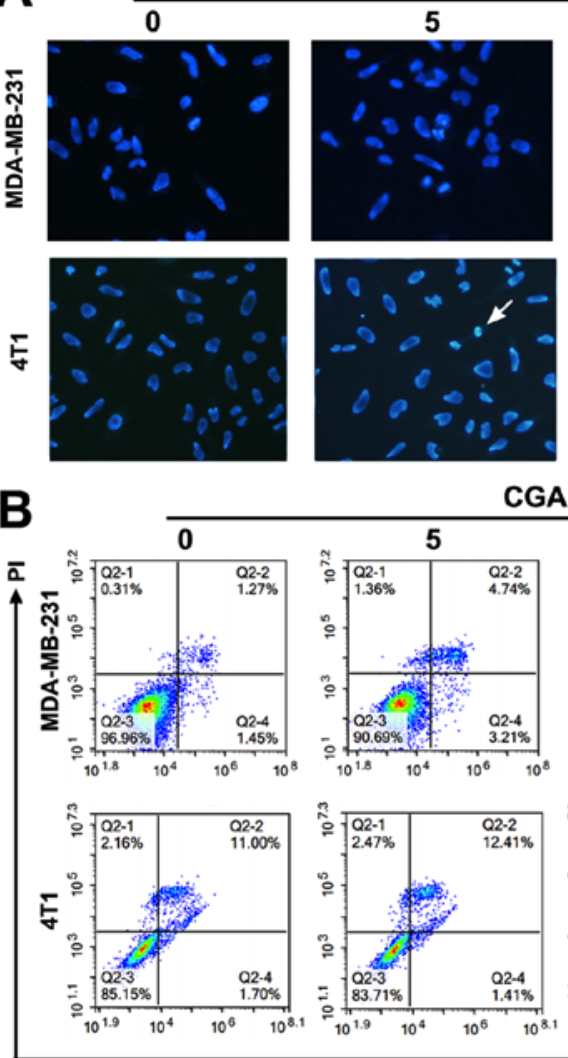

$\operatorname{CGA}(\mu \mathrm{M})$
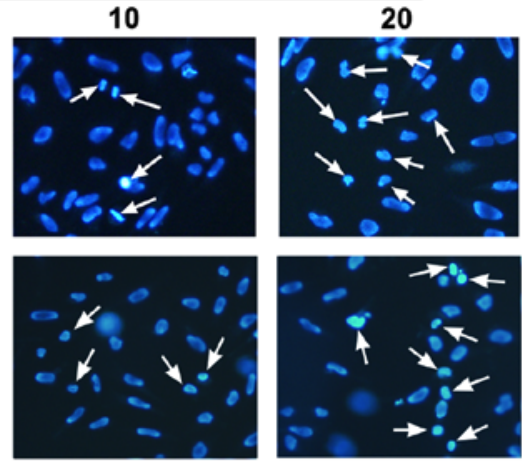

GA $(\mu \mathrm{M})$
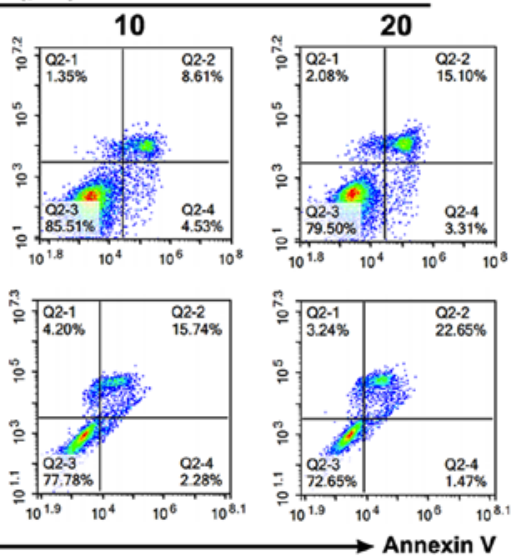
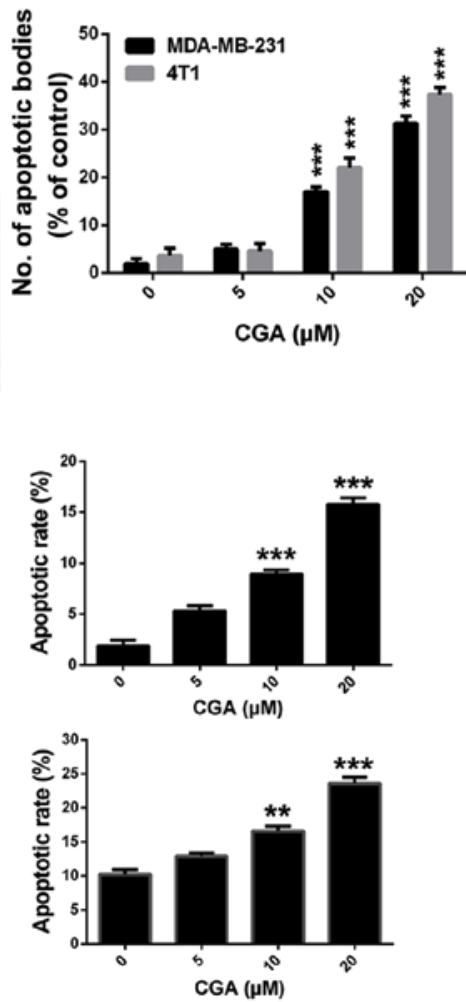

Figure 2. CGA induces apoptosis in breast cancer cells. (A) The morphologies of MDA-MB-231 and 4T1 cells were observed by microscope after treatment with CGA for $24 \mathrm{~h}$. (B) The apoptotic rates of MDA-MB-231 and 4T1 cells were detected by Annexin V/PI dual staining methods after treatment with CGA for $24 \mathrm{~h}$. Bars represent the means \pm SD of at least three independent experiments.** $\mathrm{P}<0.01$ and ${ }^{* * *} \mathrm{P}<0.001$ in comparison with the control group. CGA, chlorogenic acid.

CGA suppresses the migration and invasion in breast cancer via the $N F-\kappa B / E M T$ signaling pathway. Migration and invasion of tumor cells are key processes for the successful metastasis from primary tumor sites to distant organs (32). Therefore, a wound-healing assay was performed to evaluate the anti-migratory effect of CGA in breast cancer cells. The migratory abilities of MDA-MB-231 and 4T1 cells were significantly $(\mathrm{P}<0.001)$ suppressed by treatment with $\mathrm{CGA}$, in comparison with the control group (Fig. 3A). Moreover, a Transwell invasion assay was conducted to assess the anti-invasive ability of CGA in breast cancer cells. Compared with the control group, CGA significantly $(\mathrm{P}<0.001)$ inhibited the invasive ability in both MDA-MB-231 and 4T1 cells (Fig. 3B), thereby demonstrating the anti-migration and anti-invasion effects of CGA in breast cancer cells.

To investigate the intrinsic anti-migration and anti-invasion mechanism of CGA in breast cancer, the expression levels of $\mathrm{NF}-\kappa \mathrm{B}$ signaling pathway-related proteins were detected after treatment with various concentrations of CGA via western blotting. The expression levels of NF- $\kappa \mathrm{B}$ p65 and $\mathrm{p}-\mathrm{I} \kappa \mathrm{B} \alpha$ in both MDA-MB-231 and 4T1 cells were significantly downregulated after various treatments with of CGA (Fig. 4A), indicating that the $\mathrm{NF}-\kappa \mathrm{B}$ signaling pathway participated the in anti-migration and anti-invasion effects of CGA in breast cancer cells. Additionally, the expression of $\mathrm{N}$-cadherin was downregulated, while the expression of E-cadherin in both MDA-MB-231 and 4T1 cells was upregulated, suggesting an impairment of the EMT process in breast cancer.
The present study also investigated the translocation of NF- $\kappa$ B p65 after treatment with CGA in MDA-MB-231 cells. $\mathrm{NF}-\kappa \mathrm{B}$ p 65 was located in both the cytoplasm and nucleus, suggesting constitutive activation of NF- $\kappa \mathrm{B}$ in MDA-MB-231 cells (Fig. 4B). After treatment with TNF- $\alpha, N F-\kappa B$ p65 protein was markedly transported into nuclei of MDA-MB-231 cells. CGA could significantly attenuate the nuclear translocation of $\mathrm{NF}-\kappa \mathrm{B}$ p 65 protein that was triggered by treatment with TNF- $\alpha$. Collectively, CGA significantly inhibited breast cancer cell migration and invasion by impairing the $\mathrm{NF}-\kappa \mathrm{B} / \mathrm{EMT}$ signaling pathway.

CGA exerts an antitumor effect in a tumor mouse model. To investigate the antitumor effect of CGA in vivo, a xenograft tumor mouse model of 4T1 cells was established to assess the tumor inhibitory effect of CGA. After treatment with 20 or $40 \mathrm{mg} / \mathrm{kg}$ of CGA, the tumor growth rate was significantly slowed in comparison with the control group (Fig. 5A). At the end point of the animal experiment, tumors of each group were isolated. Treatment with CGA significantly $(\mathrm{P}<0.001)$ diminished the volume and weight of tumors in comparison with the control group (Fig. 5B and C). Moreover, compared with the control group, the survival rate of tumor-bearing mice was significantly prolonged after treatment with various concentrations of CGA (Fig. 5D).

Immunohistochemistry was conducted to further evaluate the antitumor mechanism of CGA. The number of proliferative cells, which were defined as Ki67-positive, in the tumor 

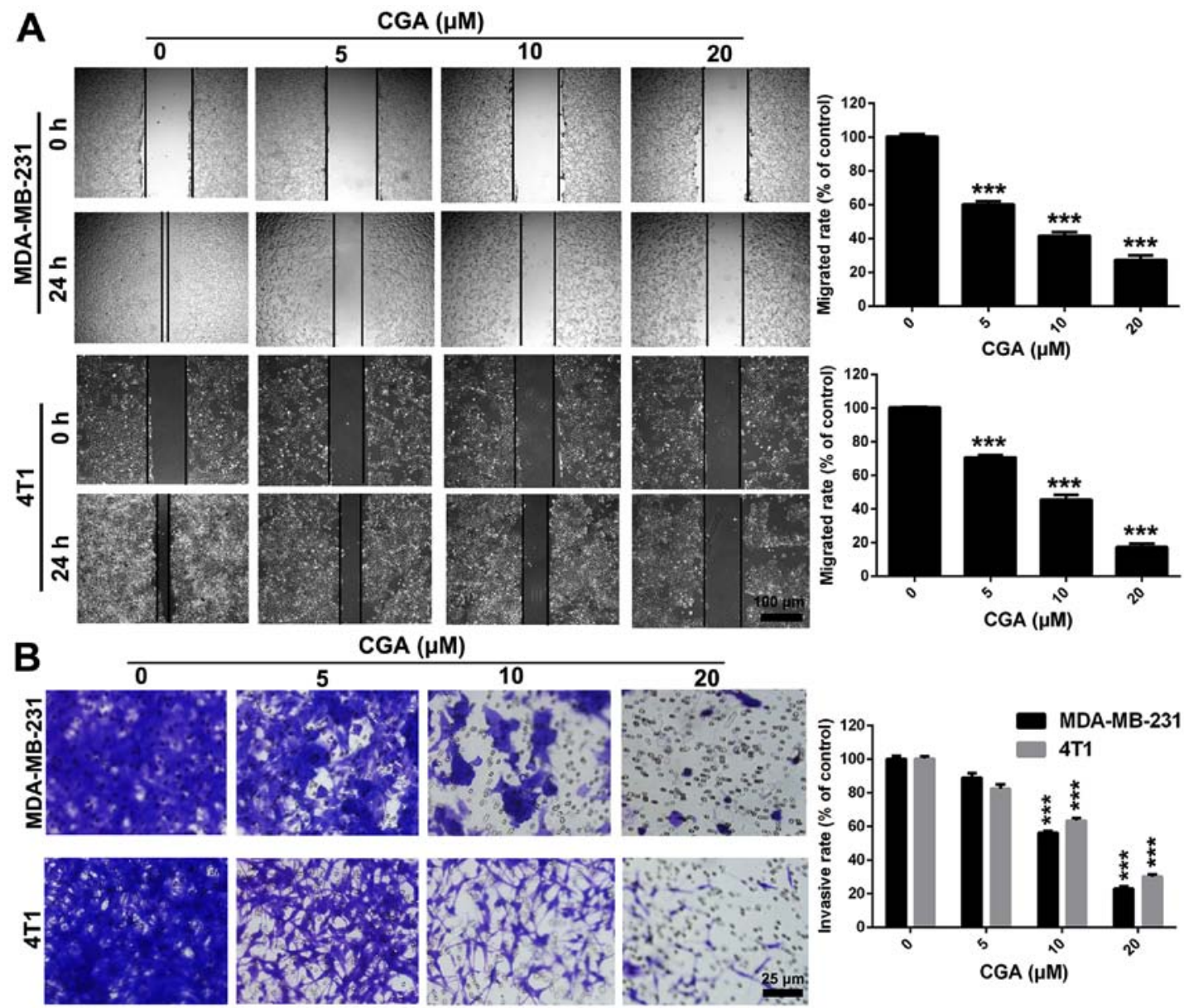

Figure 3. CGA inhibits migration and invasion of breast cancer cells. (A) Migrated abilities of MDA-MB-231 and 4T1 cells were evaluated by wound-healing assay after treatment with CGA. (B) Abilities of invasion of MDA-MB-231 and 4T1 cells were assessed by Transwell invasion assay after exposure to various doses of CGA $(0,5,10$ and $20 \mu \mathrm{M})$. Bars represent the means \pm SD of at least three independent experiments. ${ }^{* * * *} \mathrm{P}<0.001$ in comparison with the control group. CGA, chlorogenic acid.

A

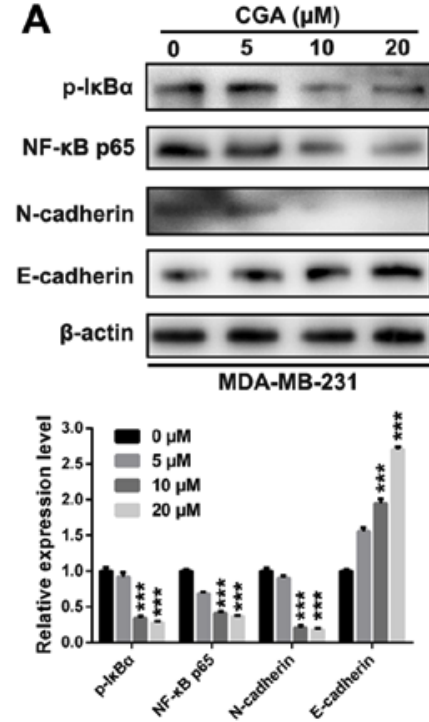

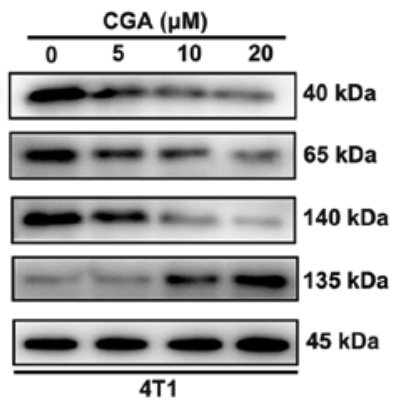

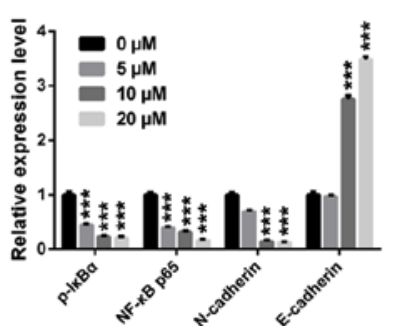

B
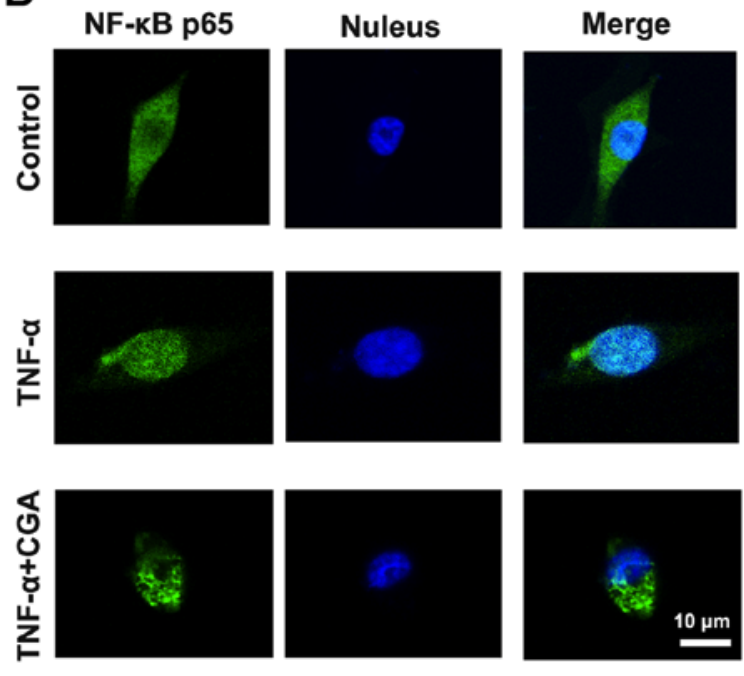

Figure 4. CGA suppresses the NF-кB/EMT signaling pathway in breast cancer cells. (A) The expression levels of key proteins which closely participate in the NF- $\mathrm{kB} / \mathrm{EMT}$ signaling pathway were assessed in MDA-MB-231 and 4T1 cells by western blotting. (B) Nuclear transcription of NF- $\mathrm{B}$ p65 protein was observed by fluorescence microscope after treatment with CGA. CGA, chlorogenic acid; EMT, epithelial-mesenchymal transition. Bars represent the means \pm SD of at least three independent experiments. ${ }^{* * *} \mathrm{P}<0.001$ in comparison with the control group. CGA, chlorogenic acid.

sections of the CGA-treated groups were significantly lower compared with that of the control group, and the expression level of cleaved caspase-3 in the CGA-treated tumor sections was upregulated (Fig. 5E). In addition, CGA could downregulate 

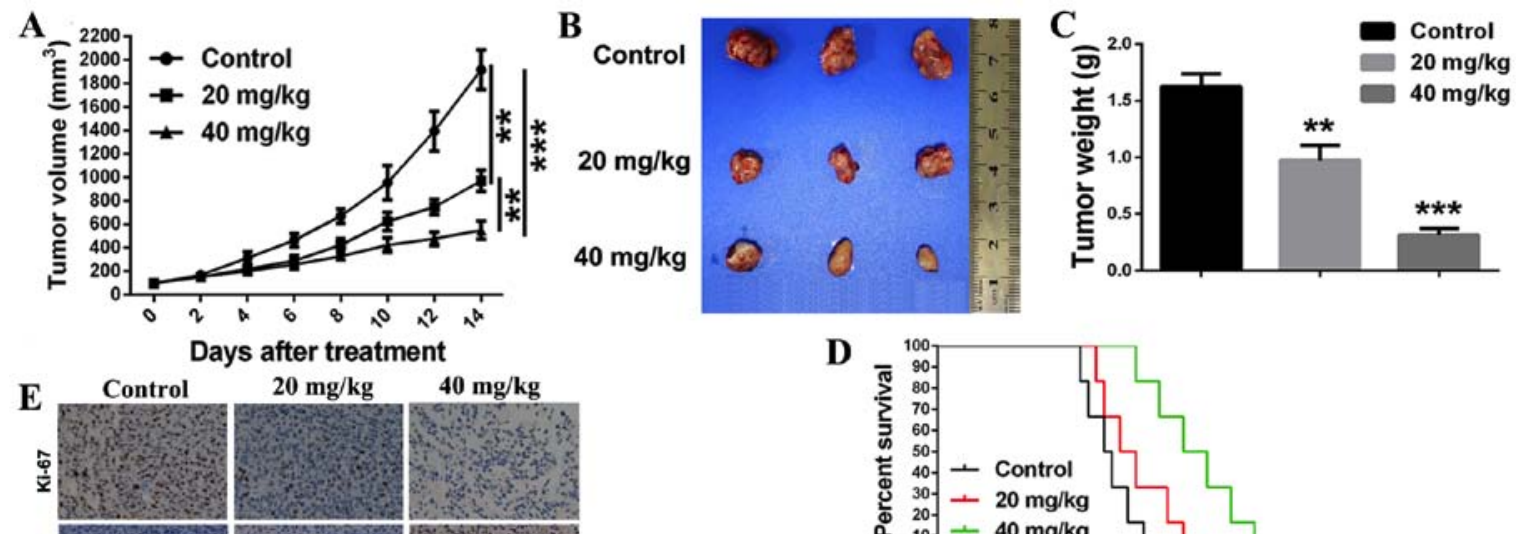

$40 \mathrm{mg} / \mathrm{kg}$

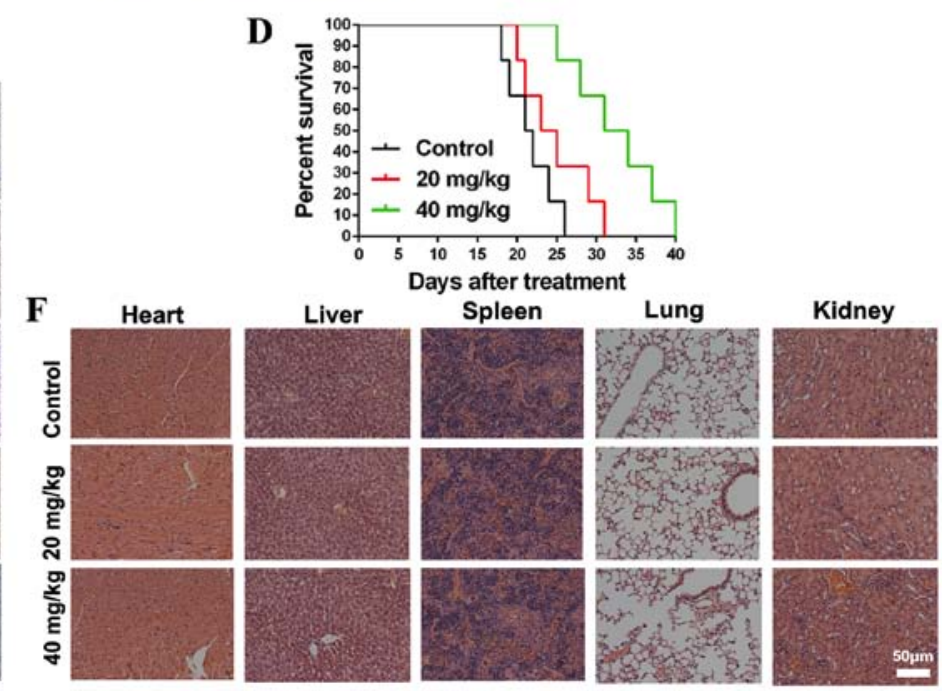

Figure 5. CGA inhibits tumor growth and prolongs the survival rate of a breast cancer mouse model. (A) The curve of tumor growth at the period of treatment. (B) Tumor images of each treated group at the termination of the experiment. (C) Tumor weight of each treated group at the termination of the experiment. (D) Survival rate of each group after treatment with different doses of CGA (0,20 and $40 \mathrm{mg} / \mathrm{kg})$. (E) Immunochemical analysis of Ki-67, cleaved caspase-3, PD-L1, N-cadherin and $\mathrm{p}-\mathrm{I} \kappa \mathrm{B} \alpha$ of tumor sections from each treated group at the termination of the experiment. (F) Pathological analysis of major organs of mice in each treated group at the termination of the experiment. Bars represent the means $\pm \mathrm{SD}$ of at least three independent experiments. ${ }^{* *} \mathrm{P}<0.01$ and ${ }^{* * * *} \mathrm{P}<0.001$ in comparison with the control group. CGA, chlorogenic acid.

the expression level of PD-L1 in the tumor sections, implying improvement in the tumor immunosuppressive microenvironment. Furthermore, compared with the control group, the expression of $\mathrm{p}$-I $\kappa \mathrm{B} \alpha$ and $\mathrm{N}$-cadherin, which are important in the NF- $\mathrm{NB}$ and EMT signaling pathways respectively, were both significantly downregulated in tumor sections after treatment with CGA. The major organs of various treated groups exhibited no pathological changes (Fig. 5F), which demonstrated that CGA had no organ toxicity. Collectively, it was indicated that CGA suppressed breast cancer proliferation and induced tumor cell apoptosis via impairing the $\mathrm{NF}-\kappa \mathrm{B}$ signaling pathway.

CGA suppresses the pulmonary metastasis of breast cancer by enhancing antitumor immunity. To further confirm whether CGA, which exhibited efficient anti-migration and anti-invasion abilities in breast cancer cells, had an anti-metastasis effect in vivo, a lung metastatic model of $4 \mathrm{~T} 1$ cells was used to assess anti-pulmonary metastasis potency of CGA. As presented in Fig. 6A, pulmonary metastasis was significantly inhibited in the CGA-treated groups. The weight of lung tissues isolated from the CGA-treated groups was lower compared with that of the control group (Fig. 6B). Furthermore, the number of metastatic nodules ( $>3$ and $<3 \mathrm{~mm}$ ) of the CGA-treated groups was decreased compared with that of the control group (Fig. 6C). Histopathological analysis of sections of isolated lung tissues identified that lung tissues of CGA treated groups had fewer metastatic nodules (Fig. 6D).
It has been reported that CGA could activate CD4 T lymphocytes by suppressing Toll-like receptor (TLR) 4 signal molecules, including TLR4, p-IRAK1, p-IкB and p-p38 (33). Thus, the present study used flow cytometry to investigate whether CGA could enhance antitumor immunity in the pulmonary metastasis mouse model of 4T1 cells. As demonstrated in Fig. 6E, the proportion of $\mathrm{CD}^{+}$and $\mathrm{CD}^{+} \mathrm{T}$ cells in spleens was significantly upregulated after treatment with CGA in comparison with the control groups. Collectively, the results demonstrated that CGA exhibited efficient anti-pulmonary metastasis effects in breast cancer by enhancing antitumor immunity.

\section{Discussion}

Breast cancer is the most common type of diagnosed cancer among women worldwide and demonstrates considerable metastatic potential, multi-drug resistance and high mortality (34). With developments in medical technology, early diagnosis of breast cancer in early stage and treatment with chemoradiation therapy on its own or in combination with surgery can efficiently suppress cancer progression. However, patients with breast cancer, especially advanced TNBC, experience an aggressive clinical outcome with a poor prognosis and high metastasis, as well as an unsatisfactory overall survival rate (4). Previous studies have revealed that abnormal activation of $\mathrm{NF}-\kappa \mathrm{B}$ is closely associated with the malignance of breast cancer, and blockade of the aberrantly activated 

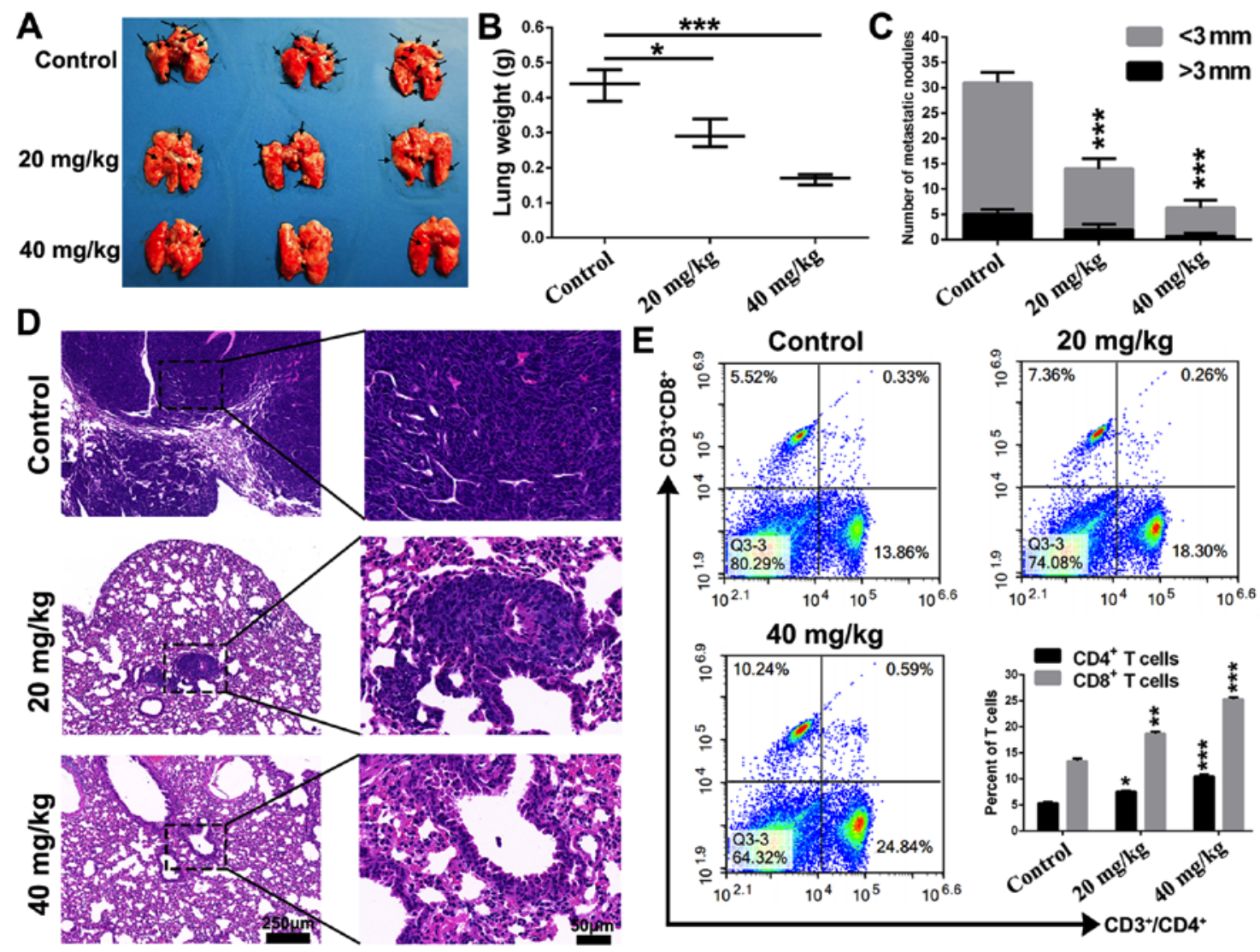

Figure 6. CGA suppresses pulmonary metastasis by improving antitumor immunity. (A) Lung tissue images of various treated groups at the end of the animal experiment. (B) Weight of lung tissues of various treated groups at the end of the animal experiment. (C) Metastatic nodules of lung tissues $(>3$ and $<3 \mathrm{~mm})$ were counted and recorded. (D) Lung tissues sections were pathologically analyzed at the termination of the experiment. (E) Proportions of CD4 ${ }^{+}$and CD8 ${ }^{+}$ $\mathrm{T}$ cells in spleens of mice in various treated groups were evaluated by flow cytometry after treatment with CGA. Bars represent the means \pm SD of at least three independent experiments. ${ }^{*} \mathrm{P}<0.05,{ }^{* *} \mathrm{P}<0.01$ and ${ }^{* * *} \mathrm{P}<0.001$ in comparison with the control group. CGA, chlorogenic acid.
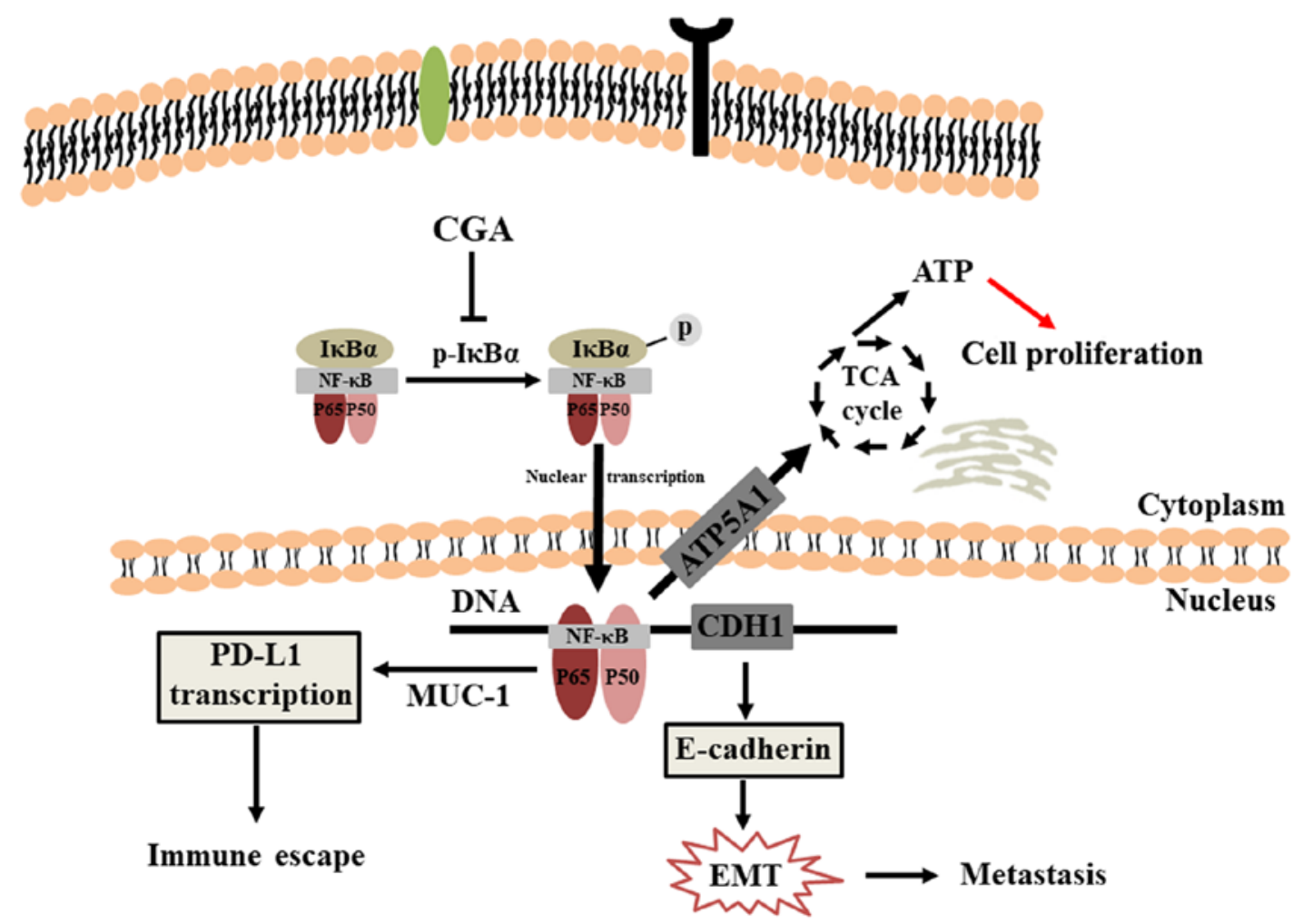

Figure 7. Overview of the pathways for the CGA-mediated antitumor effects on breast cancer cells. CGA induced apoptosis, suppressed metastasis and improved antitumor immunity by inhibiting the NF-kB signaling pathway in breastcancer cells. CGA, chlorogenic acid. 
$\mathrm{NF}-\kappa \mathrm{B}$ could trigger apoptosis and suppress metastasis in breast cancer cells (18-20). Thus, targeting NF- $\kappa \mathrm{B}$ may be a potential method for therapy of breast cancer. In the present study, CGA, a potent natural inhibitor derived from cocoa and coffee, was assessed for its antitumor efficacy in breast cancer in vitro and in vivo.

The present results firstly demonstrated that CGA exhibited potent cytotoxicity in breast cancer cells in a concentrationand time-dependent manner, while significantly inhibited the breast cancer cell colony formation ability. Furthermore, CGA could not significantly impair the viability or inhibit colony formation in human mammary epithelial cells (MCF-10A), indicating that CGA could selectively impair viability and inhibit proliferation in breast cancer cells. Next, it was investigated whether the anti-proliferation effect of CGA on breast cancer cells was caused by apoptotic induction. Results of Hoechst and Annexin V/PI dual staining demonstrated that CGA significantly induced condensed nuclei and nuclear fragmentations, as well as triggered apoptosis in breast cancer cells. However, the proportion of apoptosis was low. The cell viability and colony formation results indicated that CGA significantly suppressed these abilities of the breast cancer cells. There may be other antitumor mechanisms of CGA in cancer therapy. For example, Huang et al (35) reported that CGA effectively treated cancer types via the induction of cancer cell differentiation, while Yamagata et al (36) demonstrated that CGA regulated stem cell marker-related gene expression in A549 human lung cancer cells. Moreover, CGA was identified to decrease the abundance of HIF-1 $\alpha$ and sphingosine kinase-1 in hypoxia-induced prostate cancer cells, thus exhibiting antitumor activity (37). Therefore, other antitumor mechanisms of CGA should be investigated in future studies.

Metastasis of early stage cancer is a huge challenge to breast cancer therapy and is a major cause of breast cancer mortality (6). Additionally, the migration and invasion of cancer cells are key steps in the primary metastasis of various cancer types (38). Therefore, it is crucial to suppress the migration and invasion of cancer cells during the treatment of cancer metastasis. The present results demonstrated that CGA could significantly inhibit the migration and invasion of breast cancer cells in a dose-dependent manner. Previous studies have reported that excessive activation of $\mathrm{NF}-\kappa \mathrm{B}$ serves a key role in cancer metastasis $(16,39)$. EMT is important for movements of cells during embryogenesis. Tumor cells can reactivate EMT programs, which increases their aggressiveness. In addition to motility, EMT is implicated in enhanced properties of stem cell and multi-drug resistance, thereby promoting recurrence, distant metastasis and resistance (40). It has been revealed that microRNA (miR)-1224-5p inhibited metastasis and EMT in colorectal cancer by targeting the SP1-mediated NF- $\kappa$ B signaling pathways (41). In addition, curcumol could inhibit the proliferation and metastasis of melanoma via the miR-152-3p/PI3K/AKT and ERK/NF- $\kappa$ B signaling pathways (42). In the present study, mechanism analysis via western blotting demonstrated that CGA significantly downregulated the expression levels of $\mathrm{NF}-\kappa \mathrm{B}$-associated proteins and EMT process-associated proteins, indicating that CGA impaired NF- $\kappa \mathrm{B}$, and then inhibited the EMT signaling pathway, thereby suppressing breast cancer cell migration and invasion. In addition, evidence has demonstrated that various signaling pathway/proteins are involved in the EMT progression of numerous cancers. Pallasch and Schumacher revealed that TGF- $\beta$, a known driver of malignancy is also an inducer of EMT in various cancers (43). It is reported that diphenyl urea derivative could serve as an inhibitor on human lung cancer cell migration by disrupting EMT via Wnt/ $\beta$-catenin and PI3K/Akt signaling (44). Research from Du et al demonstrated that chronic stress promotes EMT-mediated metastasis through activation of the STAT3 signaling pathway by miR-337-3p in breast cancer (45). The EMT signaling pathway, as an axis center, has been revealed to largely participate in the regulation of cancer metastasis (46).

The antitumor effect of CGA was evaluated in a subcutaneous tumor mouse model of $4 \mathrm{~T} 1$ cells. In vivo results demonstrated that CGA significantly slowed tumor growth and diminished tumor weight by inhibiting tumor cell proliferation and suppressing the NF- $\mathrm{B}$ signaling pathway. Moreover, the survival rate of tumor-bearing mice was significantly improved after treatment with CGA. In the pulmonary metastasis model of 4T1, treatment with CGA significantly decreased metastatic nodules in lung tissues. Tumor immune escape, which is featured as suppressive antitumor immunity, is responsible for tumor malignancy and distant metastasis (47). Based on the efficient anti-metastasis efficacy of CGA, the present study investigated the effect of CGA on antitumor immunity. The results indicated that treatment with CGA significantly upregulated the proportion of $\mathrm{CD}^{+}$and $\mathrm{CD} 8^{+}$ $\mathrm{T}$ cells in the spleens of tumor-bearing mice, indicating that CGA could improve antitumor immunity. The possible reason why CGA enhances antitumor immunity may be that CGA could regulate the tumor immune microenvironment via the repolarization of macrophages from the M2 to the M1 phenotype (48). Further studies should be performed to investigate the regulatory effect and mechanism of CGA on the tumor immune microenvironment.

In conclusion, the present study provides important information regarding the antitumor activity of CGA in breast cancer (Fig. 7). The results demonstrated that CGA could significantly inhibit viability and induce apoptosis in breast cancer cells. Additionally, CGA suppressed the migration and invasion of breast cancer cells by impairing the $\mathrm{NF}-\kappa \mathrm{B} / \mathrm{EMT}$ signaling pathway. Furthermore, CGA significantly slowed tumor growth, prolonged the survival rate and inhibited pulmonary metastasis by increasing the proportion of $\mathrm{CD}^{+}$ and $\mathrm{CD}^{+} \mathrm{T}$ cells in spleens, thus improving antitumor immunity.

\section{Acknowledgements}

Not applicable.

\section{Funding}

The present study was supported by the Chinese Postdoctoral Science Foundation Program (grant no. 2019M653833XB), the Foundation of Science and Technology Department of Sichuan Province (grant no. 2020YJ0147), the Foundation of 'Apricot Grove Scholar' of Chengdu University of Traditional Chinese Medicine (grant no. 2019yky09), the Postdoctoral Science Foundation of Chengdu University of Traditional Chinese 
Medicine (grant no. 030054080), and the Foundation of Sichuan Academy of Chinese Medical Science (grant no. A-2019N-16).

\section{Availability of data and materials}

The data that support the findings of this study are available from the corresponding author upon reasonable request.

\section{Authors' contributions}

QZ, JZ and LS designed the research and were responsible for the project conception. AZ, SZ and XL performed experiments and acquired the data. LS, AZ, SW and CL were responsible for statistical analyses and interpretation of the data. LS drafted the manuscript, along with SZ and CL. LS revised the manuscript, along with JZ and SW. All authors read and approved the final version of the manuscript.

\section{Ethics approval and consent to participate}

This article does not contain any studies with human participants performed by any of the authors. All the animal experiments in the present study were performed according to the National Institutes of Health guidelines and were approved by the Institutional Animal Care and Treatment Committee of Chengdu University of Traditional Chinese Medicine.

\section{Patient consent for publication}

Not applicable.

\section{Competing interests}

All the authors declare that they have no competing interests.

\section{References}

1. Waks AG and Winer EP: Breast cancer treatment: A Review. JAMA 321: 288-300, 2019.

2. Bray F, Ferlay J, Soerjomataram I, Siegel RL, Torre LA and Jemal A: Global cancer statistics 2018: GLOBOCAN estimates of incidence and mortality worldwide for 36 cancers in 185 countries. CA Cancer J Clin 68: 394-424, 2018.

3. Siegel RL, Miller KD and Jemal A: Cancer statistics, 2020. CA Cancer J Clin 70: 7-30, 2020.

4. Couch FJ, Hart SN, Sharma P, Toland AE, Wang X, Miron P, Olson JE, Godwin AK, Pankratz VS, Olswold C, et al: Inherited mutations in 17 breast cancer susceptibility genes among a large triple-negative breast cancer cohort unselected for family history of breast cancer. J Clin Oncol 33: 304-311, 2015.

5. Claessens AK, Erdkamp FL, Lopez-Yurda M, Bouma JM, Rademaker-Lakhai JM,Honkoop AH,de GraafH, Tjan-Heijnen VC and Bos ME: Secondary analyses of the randomized phase III Stop\&Go study: Efficacy of second-line intermittent versus continuous chemotherapy in HER2-negative advanced breast cancer. Acta Oncol 59: 1-10, 2020.

6. Bale R, Putzer D and Schullian P: Local treatment of breast cancer liver metastasis. Cancers (Basel) 11: 11, 2019.

7. Song L, Chen X, Mi L, Liu C, Zhu S, Yang T, Luo X, Zhang Q, Lu H and Liang X: Icariin-induced inhibition of SIRT6/NF-kappaB triggers redox mediated apoptosis and enhances anti-tumor immunity in triple-negative breast cancer. Cancer Sci 11: 4242-4256, 2020

8. Zeng A, Liang X, Zhu S, Liu C, Luo X, Zhang Q and Song L: Baicalin, a potent inhibitor of NF-kappaB signaling pathway, enhances chemosensitivity of breast cancer cells to docetaxel and inhibits tumor growth and metastasis both in vitro and in vivo. Front Pharmacol 11: 879, 2020.
9. Sen R and Baltimore D: Multiple nuclear factors interact with the immunoglobulin enhancer sequences. Cell 46: 705-716, 1986.

10. Baldwin AS Jr: The NF-kappa B and I kappa B proteins: New discoveries and insights. Annu Rev Immunol 14: 649-683, 1996.

11. Kumar A, Takada Y, Boriek AM and Aggarwal BB: Nuclear factor-kappaB: Its role in health and disease. J Mol Med (Berl) 82: 434-448, 2004

12. Wong ET and Tergaonkar V: Roles of NF-kappaB in health and disease: Mechanisms and therapeutic potential. Clin Sci (Lond) 116: 451-465, 2009.

13. Gyrd-Hansen M and Meier P: IAPs: From caspase inhibitors to modulators of NF-kappaB, inflammation and cancer. Nat Rev Cancer 10: 561-574, 2010.

14. Cao Y, Luo JL and Karin M: IkappaB kinase alpha kinase activity is required for self-renewal of ErbB2/Her2-transformed mammary tumor-initiating cells. Proc Natl Acad Sci USA 104: 15852-15857, 2007.

15. Huang S, Pettaway CA, Uehara H, Bucana CD and Fidler IJ: Blockade of NF-kappaB activity in human prostate cancer cells is associated with suppression of angiogenesis, invasion, and metastasis. Oncogene 20: 4188-4197, 2001.

16. Poligone $B$ and Baldwin AS: Positive and negative regulation of NF-kappaB by COX-2: Roles of different prostaglandins. J Biol Chem 276: 38658-38664, 2001

17. Ahmad A, Biersack B, Li Y, Kong D, Bao B, Schobert R, Padhye S and SarkarF: Targeted regulation of PI3K/Akt/mTOR/NF-kappaB signaling by indole compounds and their derivatives: Mechanistic details and biological implications for cancer therapy. Anticancer Agents Med Chem 13: 1002-1013, 2013

18. Zhen X, Choi HS, Kim JH, Kim SL, Ren Liu R, Yun BS and Lee DS: Machilin D, a lignin derived from Saururus chinensis, suppresses breast cancer stem cells and inhibits NF-kappaB signaling. Biomolecules 10: 245, 2020.

19. Senthil Kumar KJ, Gokila Vani M, Hsieh HW, Lin CC, Liao JW, Chueh PJ and Wang SY: MicroRNA-708 activation by glucocorticoid receptor agonists regulate breast cancer tumorigenesis and metastasis via downregulation of NF-kappaB signaling. Carcinogenesis 40: 335-348, 2019.

20. Orlova Z, Pruefer F, Castro-Oropeza R, Ordaz-Ramos A, Zampedri C, Maldonado V, Vazquez-Santillan K and MelendezZajgla J: IKKepsilon regulates the breast cancer stem cell phenotype. Biochim Biophys Acta Mol Cell Res 1866: 598-611, 2019.

21. Meng S, Cao J, Feng Q, Peng J and Hu Y: Roles of chlorogenic Acid on regulating glucose and lipids metabolism: A review. Evid Based Complement Alternat Med 801457: 2013, 2013.

22. dos Santos MD, Almeida MC, Lopes NP and de Souza GE: Evaluation of the anti-inflammatory, analgesic and antipyretic activities of the natural polyphenol chlorogenic acid. Biol Pharm Bull 29: 2236-2240, 2006.

23. Kono Y, Kobayashi K, Tagawa S, Adachi K, Ueda A, Sawa Y and Shibata $\mathrm{H}$ : Antioxidant activity of polyphenolics in diets. Rate constants of reactions of chlorogenic acid and caffeic acid with reactive species of oxygen and nitrogen. Biochim Biophys Acta 1335: 335-342, 1997

24. Neuwirthova J, Gal B, Smilek P and Urbankova P: Coffee in cancer chemoprevention. Klin Onkol 30: 106-114, 2017.

25. Luo C, Xu X, Wei X, Feng W, Huang H, Liu H, Xu R, Lin J, Han L and Zhang D: Natural medicines for the treatment of fatigue: Bioactive components, pharmacology, and mechanisms. Pharmacol Res 148: 104409, 2019.

26. Buldak RJ, Hejmo T, Osowski M, Bułdak L, Kukla M, Polaniak R and Birkner E: The impact of coffee and its selected bioactive compounds on the development and progression of colorectal cancer in vivo and in vitro. Molecules 23: 3309, 2018.

27. Feng R, Lu Y, Bowman LL, Qian Y, Castranova V and Ding M: Inhibition of activator protein-1, NF-kappaB, and MAPKs and induction of phase 2 detoxifying enzyme activity by chlorogenic acid. J Biol Chem 280: 27888-27895, 2005.

28. Kang NJ, Lee KW, Kim BH, Bode AM, Lee HJ, Heo YS, Boardman L, Limburg P, Lee HJ and Dong Z: Coffee phenolic phytochemicals suppress colon cancer metastasis by targeting MEK and TOPK. Carcinogenesis 32: 921-928, 2011.

29. Zhang T, Chen S, Chen L, Zhang L, Meng F, Sha S, Ai C and Tai J: Chlorogenic acid ameliorates lead-induced renal damage in mice. Biol Trace Elem Res 189: 109-117, 2019.

30. Tian L, Su CP, Wang Q, Wu FJ, Bai R, Zhang HM, Liu JY, Lu WJ, Wang W, Lan F, et al: Chlorogenic acid: A potent molecule that protects cardiomyocytes from TNF-alpha-induced injury via inhibiting NF-kappaB and JNK signals. J Cell Mol Med 23: 4666-4678, 2019. 
31. Arfian N, Wahyudi DA, Zulfatina IB, Citta AN, Anggorowati N, Multazam A, Romi MM and Sari DC: Chlorogenic acid attenuates kidney ischemic/reperfusion injury via reducing inflammation, tubular injury, and myofibroblast formation. BioMed Res Int 5423703: 2019, 2019.

32. Hamidi $\mathrm{H}$ and Ivaska J: Every step of the way: Integrins in cancer progression and metastasis. Nat Rev Cancer 18: 533-548, 2018.

33. Yuan Y, Gong X, Zhang L, Jiang R, Yang J, Wang B and Wan J: Chlorogenic acid ameliorated concanavalin A-induced hepatitis by suppression of Toll-like receptor 4 signaling in mice. Int Immunopharmacol 44: 97-104, 2017.

34. Peart O: Metastatic breast cancer. Radiol Technol 88: 519M-539M, 2017.

35. Huang S, Wang LL, Xue NN, Li C, Guo HH, Ren TK, Zhan Y, Li WB, Zhang J, Chen XG, et al: Chlorogenic acid effectively treats cancers through induction of cancer cell differentiation. Theranostics 9: 6745-6763, 2019.

36. Yamagata K, Izawa Y, Onodera D and Tagami M: Chlorogenic acid regulates apoptosis and stem cell marker-related gene expression in A549 human lung cancer cells. Mol Cell Biochem 441: 9-19, 2018.

37. Lee MS, Lee SO, Kim KR and Lee HJ: Sphingosine kinase-1 involves the inhibitory action of HIF-1alpha by chlorogenic acid in hypoxic DU145 cells. Int J Mol Sci 18: 325, 2017.

38. Friedl $\mathrm{P}$ and Wolf K: Tumour-cell invasion and migration: Diversity and escape mechanisms. Nat Rev Cancer 3: 362-374, 2003.

39. Bollrath J and Greten FR: IKK/NF-kappaB and STAT3 pathways: Central signalling hubs in inflammation-mediated tumour promotion and metastasis. EMBO Rep 10: 1314-1319, 2009.

40. Aiello NM and Kang Y: Context-dependent EMT programs in cancer metastasis. J Exp Med 216: 1016-1026, 2019.
41. Li J, Peng W, Yang P, Chen R, Gu Q, Qian W, Ji D, Wang Q, Zhang Z, Tang J, et al: MicroRNA-1224-5p inhibits metastasis and epithelial-mesenchymal transition in colorectal cancer by targeting SP1-mediated NF-kappaB signaling pathways. Front Oncol 10: 294, 2020.

42. Ning N, Liu S, Liu X, Tian Z, Jiang Y, Yu N, Tan B, Feng H, Feng X and Zou L: Curcumol inhibits the proliferation and metastasis of melanoma via the miR-152-3p/PI3K/AKT and ERK/NF-kappaB signaling pathways. J Cancer 11: 1679-1692, 2020.

43. Pallasch FB and Schumacher U: Angiotensin inhibition, TGF-beta and EMT in cancer. Cancers (Basel) 12: 2785, 2020.

44. Dai B, Fan M, Yu R, Su Q, Wang B, Yang T, Liu F and Zhang Y: Novel diphenyl urea derivative serves as an inhibitor on human lung cancer cell migration by disrupting EMT via Wnt/beta-catenin and PI3K/Akt signaling. Toxicol In Vitro 69: 105000, 2020.

45. Du P, Zeng H, Xiao Y, Zhao Y, Zheng B, Deng Y, Liu J, Huang B, Zhang X, Yang K, et al: Chronic stress promotes EMT-mediated metastasis through activation of STAT3 signaling pathway by miR-337-3p in breast cancer. Cell Death Dis 11: 761, 2020.

46. Pastushenko I and Blanpain C: EMT Transition States during Tumo Progression and Metastasis. Trends Cell Biol 29: 212-226, 2019.

47. Mohme M, Maire CL, Schliffke S, Joosse SA, Alawi M, Matschk J, Schüller U, Dierlamm J, Martens T, Pantel K, et al: Molecular profiling of an osseous metastasis in glioblastoma during checkpoint inhibition: Potential mechanisms of immune escape. Acta Neuropathol Commun 8: 28, 2020.

48. Xue N, Zhou Q, Ji M, Jin J, Lai F, Chen J, Zhang M, Jia J, Yang H, Zhang J, et al: Chlorogenic acid inhibits glioblastoma growth through repolarizating macrophage from M2 to M1 phenotype. Sci Rep 7: 39011, 2017.

This work is licensed under a Creative Commons

Attribution-NonCommercial-NoDerivatives 4.0 International (CC BY-NC-ND 4.0) License. 